DOI: 10.20472/IAC.2018.042.001

\author{
RIČARDAS BARTKEVIČIUS \\ Lithuanian University of Educational Sciences, Lithuania \\ VAIVA JUCEVIČIŪTĖ-BARTKEVIČIENĖ \\ Lithuanian University of Educational Sciences, Lithuania \\ AGNE் JUŠKEVIČIENĖ \\ Lithuanian University of Educational Sciences, Lithuania
}

\title{
ETHNO-CULTURAL EDUCATION: INTERCULTURAL AND SOCIAL INTEGRATION OF NATIONAL MINORITIES
}

\begin{abstract}
:
Multicultural coherence in Lithuania as in all EU is still an aspiration, and its fostering is particularly actual in the face of the "new movement of nations", i.e. with the growing influx of immigrants from different countries and in the context of strengthening of nationalism.

As a rule, national minorities remain loyal to the country they live in, however, if they lose their loyalty for a variety of reasons (national and social exclusion, unsatisfactory self-expression needs in the cultural context, etc.) this could have very serious consequences even for the survival of the whole state.

Fostering the ethnic culture of ethnic minorities (especially in early age), the search for contact points with the culture of the country in which they live, and intensive communication with the local community - these could be the factors that correct strained socio-cultural or even political situations. Promoters of the cultural heritage emphasize that the opening up of cultural values to the rest of the world, the preservation of ethno-culture, does not encourage cultural closure, and it is a completely opposite phenomenon to nationalism, chauvinism, fundamentalism. The future of human civilization is multicultural diversity and the cultivation of cultural dialogues.

The aim of the research - to reveal the music and art teachers' approach, who are involved in art activities (preschool education) of children of national minorities, towards their ethno-cultural education. This aim is connected with the research questions: do children of national minorities have the need to cherish their ethno-culture; how do they adopt the ethno-culture of the country they live; how do the parents react to the integration of their children into ethno-cultural activities, which are connected with the country they live and with their own nationality; how could the ethno-cultural education interact with the social integration?

The theoretical analysis involved the scientific literature and documents, the empirical research was carried out using interviews. Qualitative research was conducted in 2018.

The interviews were performed with the music and art teachers of preschool education from Lithuania and Norway. The total sample consisted of 20 informants. The qualitative content analysis was applied processing the accumulated data.

Main results show that that appropriate music and art ethno-cultural activities adapted for education of preschool children could have positive influence on the social integration of children of national minorities in the country in which they live and to strengthen intercultural dialogue.
\end{abstract}

\section{Keywords:}

Ethno-culture, preschool education, national minorities 
JEL Classification: $120,121,124$ 